\title{
Insurance activity and economic performance: \\ Fresh evidence from asymmetric panel causality tests
}

\author{
Abdulnasser Hatemi-J \\ Department of Economics and Finance, UAE University, Al Ain, United Arab Emirates \\ Chi-Chuan Lee \\ School of Management, Beijing Normal University Zhuhai, Zhuhai, China \\ Chien-Chiang Lee* \\ Department of Finance, National Sun Yat-sen University, Kaohsiung, Taiwan \\ Phone: 886-7-5252000 ext. 4825 \\ Fax: 886-7-5254899 \\ Email: cclee@cm.nsysu.edu.tw \\ Rangan Gupta \\ Department of Economics, University of Pretoria, South Africa
}

June 18, 2018

* Corresponding author. Chien-Chiang Lee, E-mail: cclee@cm.nsysu.edu.tw (C.-C. Lee). Tel.: 886-75252000 ext. 4825; Fax: 886-7-5254899. 


\begin{abstract}
Insurance plays a fundamental role in any modern economy, but the literature has not accounted for the potential asymmetric causal impacts from the dynamic interaction between the insurance market and economic performance. This paper aims to fill this gap by studying the causal relationship between several measures of insurance per capita and real GDP per capita in the G7 countries over the period 1980-2014 via asymmetric panel causality tests. Our results show that insurance market activity and economic performance exhibit bidirectional causalities, but their direction, intensity, and significance are different due to distinct market situations. In general, insurance activity plays a passive role on economic performance, while economic performance has an aggressive role on insurance activity. These findings offer several useful insights for policy-makers and researchers.
\end{abstract}

Keywords: Insurance market activity, GDP per capita, Asymmetric panel causality, G7 countries.

JEL Classifications: C33, G22, O16. 


\section{INTRODUCTION}

Insurance is a crucial integral part of any modern economy, as it not only facilitates a myriad of economic transactions through risk transfer and indemnification, but also plays a vital financial intermediary role (Kugler and Ofoghi, 2005). ${ }^{1}$ A considerable amount of literature has been devoted to understanding the interrelationship between insurance market activities and economic performance, and along with many different econometric models there is a variety of conflicting results. A number of issues still remain unsolved. First, although the literature has documented a generally positive relationship between insurance activity and economic performance (see Outreville, 2013, for a comprehensive survey), recent evidence shows that finance has no effect on growth, which is known as the 'vanishing effect' of financial depth (Rousseau and Wachtel, 2011; Arcand et al., 2015), or even has an adverse effect, thus supporting the novel view of the 'too much finance' hypothesis (Law and Singh, 2014; Samargandi et al., 2015; Lee et al., 2016, 2017). While the linkage between insurance market activities and economic activities has been a core issue of debate worth deeper investigation, it lacks any concrete consensus.

Second, from a theoretical point of view, the 'supply-leading' and 'demandfollowing' views as presented by Patrick (1966) postulate that either the growth in financial systems speeds up economic growth, or alternatively, economic activity pushes forward financial development. For the empirical aspect, much attention has been paid to the impact of insurance market activity on economic performance (Beenstock et al., 1988; Haiss and Sümegi, 2008) or the effect of economic performance on insurance market activity (Outreville, 1990; Browne and Kim, 1993; Beck and Webb, 2003). Knowledge is limited as to understanding the causal relationships between insurance market development and economic performance. Even though a few studies have addressed the causal nexus between insurance activities and economic performance (e.g., Ward and Zurbruegg, 2000; Lee et al., 2013; Chang et al., 2014), the causality technique used therein only suggests which variables have statistically significant impacts on the other variable in the system regardless of whether unexpected changes in the given variable have an effect on the other variables. In addition, the standard causality method implicitly assumes that the impact of a positive shock is the same as the impact of a 
negative shock in absolute terms. This assumption appears to be too strong, as economic individuals react differently to a positive shock compared to a negative shock (Hatemi-J, 2012).

Third, it is widely acknowledged that asymmetric impacts prevail in many markets. In financial markets, people react more to negative news than to positive news (Hatemi-J et al., 2016). A positive unexpected shock can increase market volatility and stock prices, whereas the effect is magnified when it is negative. This non-linear behavior results from the presence of market frictions and transaction costs, or the asymmetric information phenomenon, as well as the interaction between heterogeneous traders (Stiglitz, 1974; McMillan, 2003). Serious consequences of functional misspecification have been among the most frequent concerns and criticisms in the systematic setting, with some recent studies on the finance-growth nexus even positing that the relationship between finance and growth is non-monotonic (e.g., Rousseau and Wachtel, 2011; Arcand et al., 2015; Haiss et al., 2016). Whether there exists an asymmetric causal relationship between insurance activities and economic performance still awaits a more in-depth exploration.

This paper therefore simultaneously bridges these gaps in the literature by investigating the asymmetric causal nexus of real income and life insurance, non-life insurance, as well as total insurance in the G7 countries over the period 1980-2014. We implement this by constructing the cumulative sums of positive and negative shocks in order to account for potential asymmetric causal effects within the panel of these countries. The G7 countries encompass the most developed economies and financial markets in the world. Given that they account for nearly $61.65 \%$ of the premium value of the world in 2014, their respective outcomes can be concisely compared and contrasted. We contribute to existing empirical analyses by utilizing the asymmetric causality panel tests proposed by Hatemi-J (2011) that explicitly account for the possibility that agents in financial markets react more to negative shocks than to positive ones. This approach also allows us to accommodate for possible instability in the causal relationships between the variables of concern, which may arise out of structural breaks (Inglesi-Lotz et al., 2014). Moreover, the application of panel data analysis has advantages in dealing with smallsample bias faced by time-series and cross-sectional analyses. Our paper thus provides more accurate results and paints a more complete picture on this important topic. 
The rest of this paper is organized as follows. Section 2 reviews the literature. Section 3 describes the underlying dataset and methodology. Section 4 presents the empirical findings. Section 5 provides further discussions and implications. The last section offers concluding remarks.

\section{LITERATURE REVIEW AND HYPOTHESES}

There is a massive amount of literature assessing the linkage between insurance market activity and economic performance, but it does so along many disparate channels and with a variety of conflicting results. One main strand of the literature discusses the impact of insurance activities on economic performance, which corresponds to the supply-leading theory. A large body of the theoretical literature has discussed how insurance affects the real economy and society (e.g., Rejda, 2005; Skipper and Kwon, 2007; Dorfman, 2008; Njegomir and Stojić, 2010). From the empirical aspect of the aggregate production function, the early study by Beenstock et al. (1988) utilizes a crosssection dataset of 12 industrialized countries over the period 1970-1981 to examine the relationship between property-liability insurance premiums, income, and interest rate, providing evidence in support of the linkage between non-life insurance and growth. Based on a sample of cross-country data of 55 countries over the period 1980-1996, Webb et al. (2005) analyze the effect of banking and insurance (life and non-life) sectors on the growth of capital and output. Evidence shows that insurance premiums have a significant impact on economic growth. Haiss and Sümegi (2008) further conduct a crosscountry panel data analysis for 29 European countries over the period 1992-2005 to investigate the impacts of both insurance investment and premiums on GDP growth. Their empirical results indicate that life insurance plays a more important positive role on economic growth in mature European countries. Using panel data from 51 developed and developing countries during 1981-2005, Azman-Saini and Smith (2011) further investigate the impact of insurance on the growth channels. Evidence shows that insurance stimulate growth primarily through productivity growth in developed countries, while it promotes capital accumulation in developing countries.

Another strand of contemporary literature aims at the influence of economic performance on insurance activities corresponding to the demand-following theory. 
Several theoretical models of insurance demand have been developed in this literature (e.g., Yarri, 1965; Hakansson, 1969; Fischer, 1973; Karni and Zilcha, 1985; and Lewis, 1989). For an empirical analysis, Outreville (1990) conducts a cross-section analysis of non-life insurance demand in a sample of 55 developing countries for the years 1983 and 1984. He finds that non-life insurance demand is positively associated with GDP per capita. Based on a cross-sectional data of 45 developing countries for the years 1980 and 1987, Browne and Kim (1993) explore the determinants of life insurance demand. Evidence shows that life insurance demand is positively associated with GDP per capita. Beck and Webb (2003) also ascertain that the demand for life insurance is positively related to income for a sample of 63 countries between 1980 and 1996.

Most existing studies only investigate either the impact of economic growth on insurance market or conversely the impact of insurance on growth, while few pay attention on the causal nexus between insurance activities and economic performance. Ward and Zurbruegg (2000) conduct a time-series analysis to examine the potential causal relationship between insurance industry growth and economic growth in a sample of 9 OECD countries over the period 1961-1996. The results show in the long run that there is a bidirectional causal relationship between real insurance premiums and real GDP for Australia, Canada, Italy, and Japan, but a unidirectional causality from real GDP to real insurance premiums for France. In the context of panel data analysis, Lee et al. (2013) investigate the stationarity properties of real life insurance premiums per capita and real GDP per capita for 41 countries within three income levels covering 1979-2007. Evidence shows that the developments of life insurance markets and economic growth exhibit both long-run and short-run bidirectional causalities. Chang et al. (2014) apply the bootstrap panel Granger causality test to examine the causal nexus between insurance market activity and economic growth for 10 OECD countries over the period 1979-2006. Empirical results show that there exist unidirectional and bidirectional Granger causalities between economic growth and the insurance market for different OECD countries. Table 1 summarizes these studies.

The existing studies on the standard causal relationship between insurance activities and economic performance are mainly based on a systematic setting. Although the bootstrap panel Granger causality test have advantages on dealing with the problem of 
Table 1 Comparative survey of the empirical results on the causal relationship between insurance activity and economic performance

\begin{tabular}{|c|c|c|c|c|}
\hline Authors & Insurance sectors & Sample countries & Methodologies & Results \\
\hline $\begin{array}{l}\text { Ward and Zurbruegg } \\
\text { (2000) }\end{array}$ & Total insurance & 9 OECD countries & Granger causality & $\begin{array}{l}\text { Bidirectional causality (Australia, Canada, Italy, and Japan) } \\
\text { Demand-following (France) } \\
\text { No causality (Austria, Switzerland, the UK and the U.S.) }\end{array}$ \\
\hline $\begin{array}{l}\text { Kugler and Ofoghi } \\
\text { (2005) }\end{array}$ & Life and Non-life & United Kingdom & Granger causality & Bidirectional causality \\
\hline $\begin{array}{l}\text { Adam et al. } \\
(2009)\end{array}$ & Global insurance & Sweden & Granger causality & Supply-leading \\
\hline Lee (2013) & Life and Non-life & 17 OECD countries & Panel causality & Bidirectional causality \\
\hline Lee et al. (2013) & Life insurance & 41 countries & Panel causality & Bidirectional causality \\
\hline $\begin{array}{l}\text { Chang et al. } \\
\text { (2014) }\end{array}$ & Life, Non-life, and Total & 10 OECD countries & $\begin{array}{l}\text { Bootstrap Granger } \\
\text { causality }\end{array}$ & $\begin{array}{l}\text { Supply-leading (All sectors: France, Japan, and the UK) } \\
\text { Demand-following (Life sector: Canada, and Italy) } \\
\text { Demand-following (Non-life sector: the U.S.) } \\
\text { Demand-following (Total sector: Italy and the U.S.) } \\
\text { Bidirectional causality (Life sector: the U.S.) } \\
\text { No causality (Non-life sector: Canada and Italy) } \\
\text { No causality (Total sector: Canada) }\end{array}$ \\
\hline $\begin{array}{l}\text { Lee et al. } \\
\text { (2016) }\end{array}$ & Life and Non-life & G7 countries & $\begin{array}{l}\text { Bootstrap Granger } \\
\text { causality }\end{array}$ & $\begin{array}{l}\text { Supply-leading (Life sectors: France and Japan) } \\
\text { Supply-leading (Non-life sectors: France and Japan) } \\
\text { Demand-following (Life sectors: Canada and the UK) } \\
\text { Bidirectional causality (Life sector: Germany) } \\
\text { Bidirectional causality (Non-life sector: Germany and Italy) } \\
\text { No causality (Life sector: Italy and the U.S.) } \\
\text { No causality (Non-life sector: Canada, the UK, and the U.S.) }\end{array}$ \\
\hline
\end{tabular}


cross-countries dependency and heterogeneity, it has been subject to criticism for failing to account for the fact that the causal impact of negative changes could be different than the causal impact of positive changes. By using the asymmetric causality panel tests proposed by Hatemi-J (2011), the present study simultaneously bridges the gaps in the literature by incorporating the potential asymmetric causal interaction between insurance activities and economic performance. The method accord well with reality since people usually tend to react more strongly to negative changes than the positive ones. Such information can enable governments to set up appropriate policies and allocate resources in a more focused manner by concentrating on which shocks affect mostly the economic performance.

\section{DATA AND METHODOLOGY}

Our dataset consists of life insurance, non-life insurance, total insurance, and GDP from 1980 to 2014 for the G7 countries of Canada, France, Germany, Italy, Japan, the UK, and the U.S. All variables are expressed in real per capita and in logarithmic form. The data for insurance premiums per capita are taken from various issues of Simga database (Swiss Reinsurance Company, 1980-2015), while GDP per capita data are sourced from World Development Indicators (WDI, 2015). To avoid issues regarding exchange rate movements, the variables are also in terms of US dollars.

Table A1 in the Appendix summarizes the descriptive statistics for all variables across countries. These statistics show that the real GDP per capita ranges from 29,801 (the UK) to 40,802 (the U.S.) over the sample period. As to the composition of the contribution of insurance to these economies, these statistics also provide a summary of the life, non-life, and total insurance business for all G7 countries. The real life insurance premiums per capita ranges from 729 (Italy) to 2,545 (Japan), while the real non-life insurance premiums per capita varies from 471 (Italy) to 1503 (the U.S.). Regarding to the total insurance sectors, it is found that the average of real total insurance premiums per capita ranges from 1,200 (Italy) to 3,236 (Japan). The Japan has the highest total insurance business, followed by the UK and the U.S.

Figure 1 presents a graphical illustration of these series and the box plots summarizing the distribution of the underlying dataset. From the time-series plots, we can 
see some upward trends for the data series, but the growth patterns differ from each other. The GDP per capita exhibits a sharp increase following the global financial crisis. Looking at the insurance markets' variables, we observe that these series are relatively stable at the beginning and exhibit a significant increase after 1985. In addition, according to the box plots, most series deviate from the normal distribution, thus suggesting the existence of abnormal, asymmetrical, and non-linear characteristics in these series.

(A) GDP per capita

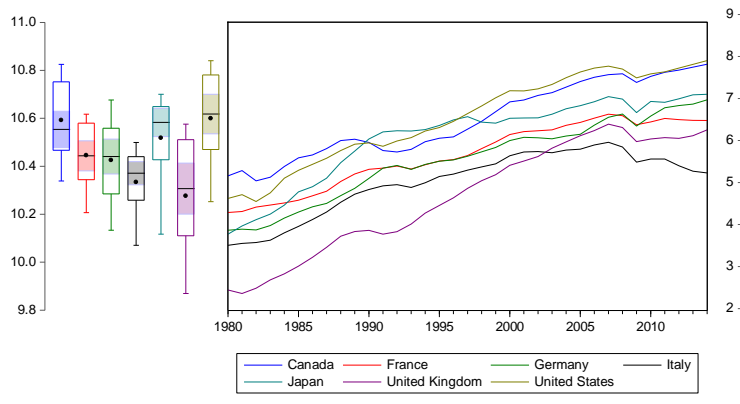

(C) Non-life insurance per capita

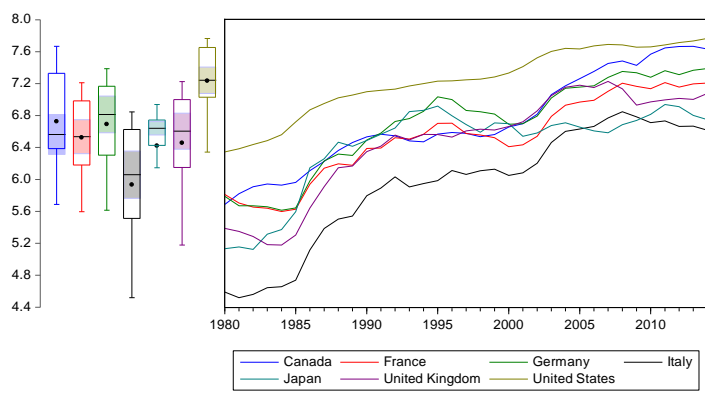

(B) Life insurance per capita

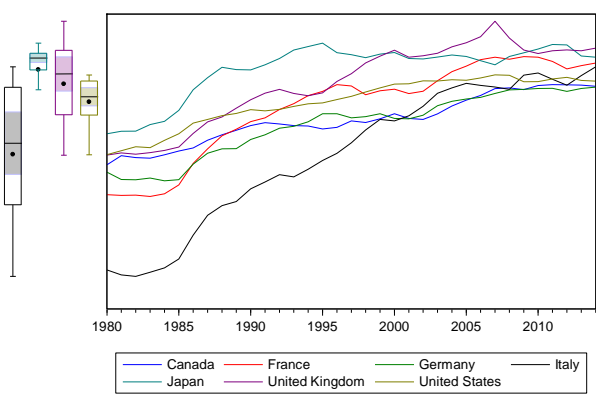

(D) Total insurance per capita

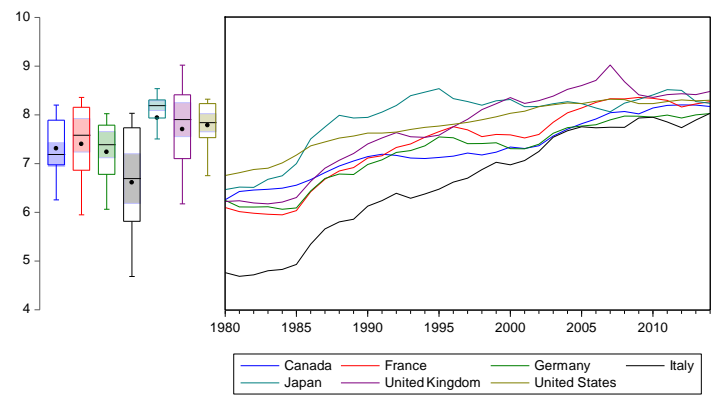

Figure 1. Plots of underlying series of G7 countries for 1980-2014 (in natural logarithm)

The well-established notion of causality proposed by Wiener-Granger is based on the idea of whether or not the past values of one time series can improve the forecast of another one. This is usually tested as a null hypothesis that puts zero restrictions on pertinent parameters within a dynamic model. Empirical support for causality is provided if the underlying null hypothesis is statistically significant. An important issue that is usually neglected within this context is accounting for potential asymmetric causal effects. To remedy this problem, Hatemi-J $(2011,2012)$ proposes asymmetric causality 
tests. Let $I_{i, t}$ signify a measure of insurance activity and let $y_{i, t}$ represent a measure of economic performance for cross-sectional unit $i$ at time $t$. These two time series are usually integrated of the first order. ${ }^{3}$ Therefore, each variable in the panel is stated as:

$$
\begin{aligned}
& I_{i, t}=I_{i, t-1}+u_{i 1, t}=I_{i, 0}+\sum_{j=1}^{t} u_{i 1, j} \\
& y_{i, t}=I_{i, t-1}+u_{i 2, t}=y_{i, 0}+\sum_{j=1}^{t} u_{i 2, j}
\end{aligned}
$$

Here, $i=1, \ldots, 7$, whereby $i$ represents the cross-country dimension since we are dealing with the G7 countries, and $u_{i}$ signifies the error term that is assumed to be a white noise process in all cases. The positive and negative shocks are defined as $u_{i 1, t}^{+}:=$ $\operatorname{Max}\left(u_{i 1, t}, 0\right), u_{i 2, t}^{+}:=\operatorname{Max}\left(u_{i 2, t}, 0\right), u_{i 1, t}^{-}:=\operatorname{Min}\left(u_{i 1, t}, 0\right)$, and $u_{i 2, t}^{-}:=\operatorname{Min}\left(u_{i 2, t}, 0\right)$ according to Hatemi-J (2011). These expressions are used for constructing the following cumulative components:

$$
\begin{aligned}
& I_{i, t}^{+}=I_{i 1,0}^{+}+u_{i 1, t}^{+}=I_{i, 0}+\sum_{j=1}^{t} u_{i 1, j}^{+} \\
& y_{i, t}^{+}=I_{i, 0}^{+}+u_{i 2, t}^{+}=y_{i, 0}+\sum_{j=1}^{t} u_{i 2, j}^{+} \\
& I_{i, t}^{-}=I_{i, 0}^{-}+u_{i 1, t}^{-}=I_{i, 0}+\sum_{j=1}^{t} u_{i 1, j}^{-} \\
& y_{i, t}^{-}=y_{i, 0}^{-}+e_{i 2, t}^{-}=y_{i, 0}+\sum_{j=1}^{t} u_{i 2, j}^{-}
\end{aligned}
$$

Here, $I_{i, 0}$ and $y_{i, 0}$ are initial values for each cross-sectional unit.

The transformed data expressed as cumulative partial sums can be used in a vector autoregressive seemingly unrelated regression model of order $k$, VAR-SUR $(k)$, for estimation. Each null hypothesis of no causality can be tested within this model. Note that this VAR-SUR $(k)$ model is capable of accounting for the fact that the error terms across the cross sectional units can be dependent. Assume that we are interested in testing for causality between negative components in the underlying panel model. In this case the vector that is used is $\left(I_{i, t}^{-}, y_{i, t}^{-}\right)$, and we need to estimate the following $\operatorname{VAR}-\operatorname{SUR}(k)$ model:

$$
\left[\begin{array}{l}
I_{i, t}^{-} \\
y_{i, t}^{-}
\end{array}\right]=\left[\begin{array}{l}
\beta_{i 0} \\
\gamma_{i 0}
\end{array}\right]+\left[\begin{array}{ll}
\sum_{r=1}^{k} \beta_{i 1, r} & \sum_{r=1}^{k} \beta_{i 2, r} \\
\sum_{r=1}^{k} \gamma_{i 1, r} & \sum_{r=1}^{k} \gamma_{i 2, r}
\end{array}\right] \times\left[\begin{array}{c}
I_{i, t-r}^{-} \\
y_{i, t-r}^{-}
\end{array}\right]+\left[\begin{array}{c}
\varepsilon_{i 1}^{-} \\
\varepsilon_{i 2}^{-}
\end{array}\right]
$$

The lag order $k$ can be selected via the minimization of an information criterion. The null hypothesis that $I_{i, t}^{-}$does not cause $y_{i, t}^{-}$for the cross-sectional unit $i$ in our panel system is expressed as:

$$
H_{0}: \gamma_{i 1, r}=0, \forall r . \text { Where } r=1, \ldots, k \text {. }
$$


The above null hypothesis can be tested by estimating a Wald test statistic that is proposed by Hatemi-J (2011). Similarly, the vector $\left(I_{i, t}^{+}, y_{i, t}^{+}\right)$can be used in order to test potential causal impacts between positive components.

\section{EMPIRICAL RESULTS}

Tables 2-7 present the estimation results for symmetric and asymmetric casualty tests within the panel system. For the nexus between life insurance activity and economic performance, the results from Table 2 show the null hypothesis that life insurance premium per capita does not cause GDP per capita, which can be rejected only in the case of Italy and Japan when the asymmetric effect is not taken into account. However, the asymmetric causality test results reveal that there exists a causal relationship running from life insurance activities to economic performance for most $\mathrm{G} 7$ countries. A positive shock in life insurance per capita causes a shock in the GDP per capita for France, Italy, Japan, and the UK, while a negative shock in life insurance per capita causes a negative shock in the GDP per capita in all countries in the sample except for the U.S. For those positive shocks, the estimated causal parameter indicates that life insurance market development has an uncertain impact on economic performance. Life insurance activities are beneficial to economic performance in France and Japan, but are harmful to economic performance in Italy and the UK. This possibility of the economy being adversely affected may be attributed to the fact of 'too much finance' (Law and Singh, 2014; Samargandi et al., 2015; Lee et al., 2016).

As to the negative shocks, strong evidence shows that a reduction in life insurance activities causes a decrease in economic performance. In addition, the causal impact of a positive change is different compared to the causal impact of a negative change in absolute terms. The negative changes have a greater impact on economic performance than the positive ones. As mentioned above, given that the G7 countries have the most developed insurance markets, an increase in insurance activities is less relevant in terms of impact if insurance market development is already good enough. However, a decrease in insurance activities is likely to reduce the function of the financial system and to hinder economic performance. Therefore, the effect of decreasing insurance market activity is larger than that of increasing activity. 
Table 2 The symmetric and asymmetric panel causality test results for the null hypothesis that life insurance per capita does not cause GDP per capita

\begin{tabular}{|c|c|c|c|c|}
\hline Country & Null Hypothesis & Test Values & P-values & $\begin{array}{c}\text { Causal } \\
\text { Parameters }\end{array}$ \\
\hline \multirow[t]{3}{*}{ Canada } & $L I \neq>R Y$ & -1.5922 & 0.1128 & \\
\hline & $L^{I^{+}} \neq>R Y^{+}$ & -1.4148 & 0.1586 & \\
\hline & $L I^{-} \neq>R Y^{-}$ & $1.9632 *$ & 0.0510 & 0.0277 \\
\hline \multirow[t]{3}{*}{ France } & $L I \neq>R Y$ & 0.8136 & 0.4168 & \\
\hline & $\mathrm{LI}^{+} \neq>\boldsymbol{R} \boldsymbol{Y}^{+}$ & $1.9409 *$ & 0.0536 & 0.0089 \\
\hline & $L I^{-} \neq>R Y^{-}$ & $3.7912 * *$ & 0.0002 & 0.0107 \\
\hline \multirow[t]{3}{*}{ Germany } & $L I \neq>R Y$ & -0.6023 & 0.5476 & \\
\hline & $\mathrm{LI}^{+} \neq>\boldsymbol{R} \boldsymbol{Y}^{+}$ & 0.6510 & 0.5158 & \\
\hline & $L I^{-} \neq>R Y^{-}$ & $3.3201 * *$ & 0.0011 & 0.0239 \\
\hline \multirow[t]{3}{*}{ Italy } & $L I \neq>R Y$ & $-4.8121 * *$ & 0.0000 & -0.0145 \\
\hline & $\boldsymbol{L I}^{+} \neq>\boldsymbol{R} \boldsymbol{Y}^{+}$ & $-2.3083 * *$ & 0.0220 & -0.0131 \\
\hline & $L I^{-} \neq>R Y^{-}$ & 7.7379 & 0.0000 & 0.1158 \\
\hline \multirow[t]{3}{*}{ Japan } & $L I \neq>R Y$ & $2.4453 * *$ & 0.0153 & 0.0230 \\
\hline & $L I^{+} \neq>R Y^{+}$ & $3.2016 * *$ & 0.0016 & 0.0405 \\
\hline & $L I^{-} \neq>R Y^{-}$ & $4.9573 * *$ & 0.0000 & 0.0236 \\
\hline \multirow[t]{3}{*}{$\mathbf{U K}$} & $L I \neq>R Y$ & 1.0292 & 0.3046 & \\
\hline & $\mathrm{LI}^{+} \neq>\mathrm{R} \boldsymbol{Y}^{+}$ & $-1.7099 *$ & 0.0888 & -0.0182 \\
\hline & $L I^{-} \neq>R Y^{-}$ & $23.3977 * *$ & 0.0000 & 0.0731 \\
\hline \multirow[t]{3}{*}{ U.S. } & $L I \neq>R Y$ & 1.1028 & 0.2713 & \\
\hline & $L I^{+} \neq>R Y^{+}$ & -0.3394 & 0.7346 & \\
\hline & $L I^{-} \neq>R Y^{-}$ & 0.7250 & 0.4693 & \\
\hline
\end{tabular}

Notes: $L I$ represents life insurance per capita and $R Y$ represents gross domestic product per capita. The vector $\left(L I^{+}, R Y^{+}\right)$signifies the cumulative positive shocks and $\left(L I^{-}, R Y^{-}\right)$denotes the cumulative negative shocks. The VAR-SUR model is estimated by using EViews 9. ** indicates significant at the $5 \%$ level, * indicates significant at the $10 \%$ level.

Table 3 lists the results for the causal impact of GDP on life insurance per capita. The symmetric causality test results show that GDP per capita Granger causes life insurance in the cases of Canada, Germany, and the U.S. In the case of positive shocks, there is causality in all countries except for France and Italy. In the case of negative shocks, there is causality in all countries except for Germany, Italy, Japan, and the UK. Positive shocks in economic performance have a positive effect on life insurance market development, while negative shocks in economic performance have a negative impact on life insurance activities. These results indicate that a high level of economic performance leads to a high level of real insurance premiums and vice versa. It should be mentioned 
that the income effect on life insurance is especially prevalent in the cases of Canada, Germany, and the U.S. In short, when standard symmetric causality is used, the empirical results indicate that there exists unidirectional causality running from life insurance activities to economic performance, thus supporting the supply-leading theory for Italy and Japan, whereas there is reverse causality for Canada, Germany, and the U.S., which favors the demand-following theory. The results are in line with Ward and Zurbruegg (2000), Chang et al. (2014) and Lee et al. (2016) who find that the causal relationships are country-specific. Put differently, when asymmetric causality tests are used, the results show that there exists a bidirectional causal relationship between insurance activities and the regional economy.

Table 3 The symmetric and asymmetric panel causality test results for the null hypothesis that GDP per capita does not cause life insurance per capita

\begin{tabular}{|c|c|c|c|c|}
\hline Country & Null Hypothesis & Test Values & P-values & $\begin{array}{c}\text { Causal } \\
\text { Parameters }\end{array}$ \\
\hline \multirow[t]{3}{*}{ Canada } & $R Y \neq>L I$ & $3.9722 * *$ & 0.0001 & 0.8751 \\
\hline & $R Y^{+} \neq>L I^{+}$ & $3.5442 * *$ & 0.0005 & 0.9399 \\
\hline & $\boldsymbol{R} \boldsymbol{Y}^{-} \neq>\boldsymbol{L I} \boldsymbol{I}^{-}$ & $2.1062 * *$ & 0.0364 & 0.4271 \\
\hline \multirow[t]{3}{*}{ France } & $R Y \neq>L I$ & 1.5550 & 0.1214 & \\
\hline & $R Y^{+} \neq>L^{+}$ & 0.4009 & 0.6889 & \\
\hline & $\boldsymbol{R} \boldsymbol{Y}^{-} \neq>\boldsymbol{L} \boldsymbol{I}^{-}$ & $2.8505 * *$ & 0.0048 & 1.8503 \\
\hline \multirow[t]{3}{*}{ Germany } & $R Y \neq>L I$ & $2.8289 * *$ & 0.0051 & 0.9378 \\
\hline & $\boldsymbol{R} \boldsymbol{Y}^{+} \neq>\boldsymbol{L} \boldsymbol{I}^{+}$ & $1.8959 *$ & 0.0593 & 0.5572 \\
\hline & $\boldsymbol{R} \boldsymbol{Y}^{-} \neq>\boldsymbol{L I} \boldsymbol{I}^{-}$ & 1.2274 & 0.2211 & \\
\hline \multirow[t]{3}{*}{ Italy } & $R Y \neq>L I$ & 0.7032 & 0.4827 & \\
\hline & $R Y^{+} \neq>L I^{+}$ & 1.1822 & 0.2385 & \\
\hline & $\boldsymbol{R} \boldsymbol{Y}^{-} \neq>\boldsymbol{L} \boldsymbol{I}^{-}$ & 1.5446 & 0.1240 & \\
\hline \multirow[t]{3}{*}{ Japan } & $R Y \neq>L I$ & 0.4622 & 0.6444 & \\
\hline & $R Y^{+} \neq>L I^{+}$ & $2.4021 * *$ & 0.0172 & 0.9749 \\
\hline & $\boldsymbol{R} \boldsymbol{Y}^{-} \neq>\boldsymbol{L I}^{-}$ & 0.5927 & 0.5540 & \\
\hline \multirow[t]{3}{*}{ UK } & $R Y \neq>L I$ & 1.1807 & 0.2390 & \\
\hline & $\boldsymbol{R} \boldsymbol{Y}^{+} \neq>\boldsymbol{L} \boldsymbol{I}^{+}$ & $3.5876 * *$ & 0.0004 & 1.4900 \\
\hline & $\boldsymbol{R} \boldsymbol{Y}^{-} \neq>\boldsymbol{L I} \boldsymbol{I}^{-}$ & 0.6355 & 0.5258 & \\
\hline \multirow[t]{3}{*}{ U.S. } & $R Y \neq>L I$ & $1.7094 *$ & 0.0888 & 0.4480 \\
\hline & $R Y^{+} \neq>L I^{+}$ & $3.4354 * *$ & 0.0007 & 0.8158 \\
\hline & $\boldsymbol{R} \boldsymbol{Y}^{-} \neq>\boldsymbol{L} \boldsymbol{I}^{-}$ & $1.6898 *$ & 0.0926 & 1.6101 \\
\hline
\end{tabular}

Notes: $L I$ represents life insurance per capita and $R Y$ represents gross domestic product per capita. The vector $\left(L I^{+}, R Y^{+}\right)$signifies the cumulative positive shocks and $\left(L I^{-}, R Y^{-}\right)$denotes the cumulative negative shocks. $* * *$ indicate significance at the $10 \%$ and $5 \%$ level, respectively. 
As to the nexus between non-life insurance activity and economic performance, Table 4 provides the causality test results for the causal impact of non-life insurance per capita on GDP per capita. The symmetric test results support the hypothesis that non-life insurance per capita causes GDP per capita in the cases of Italy, Japan and the U.S. The asymmetric causality test results, however, show that a positive shock in non-life insurance per capita causes a positive shock in GDP per capita in Canada and Japan only. For most G7 countries, non-life insurance has no effect on economic performance, which is consistent with the 'vanishing effect' of financial depth (Rousseau and Wachtel, 2011; Arcand et al., 2015). For negative shocks, causality is found in all countries, which means that a negative shock in the non-life insurance per capita of any country in the panel will cause a negative shock in the GDP per capita of that country. Furthermore, the causal impact of negative change is greater than those of positive changes in absolute terms.

Table 5 presents the empirical findings pertinent to the causal impact of GDP per capita on non-life insurance per capita. These results indicate that GDP influences nonlife insurance in Canada, Germany, and the U.S. when asymmetric impacts are not accounted for. In the case of asymmetric causality we find that a positive shock in GDP causes a positive shock in non-life insurance in Canada, Germany, Japan, the UK, and the U.S. For negative shocks, causality is only found in Canada, Germany, Italy, and the UK. In short, the results of the standard symmetric causality test indicate that the causal relationships between the non-life insurance market and the economy are country-specific. A feedback between non-life insurance activity and economic performance exists for the U.S. only. However, when asymmetric causality effects are considered, a bidirectional causal relationship between insurance activities and economic performance is supported. In addition, compared to the results of life and non-life insurance markets, evidence shows that development in the non-life insurance market has a greater impact on economic performance than activities in the life insurance market do, which is consistent with the results of Lee (2013). 
Table 4 The symmetric and asymmetric panel causality test results for the null hypothesis that non-life insurance per capita does not cause GDP per capita

\begin{tabular}{|c|c|c|c|c|}
\hline Country & Null Hypothesis & Test Values & P-values & $\begin{array}{c}\text { Causal } \\
\text { Parameters }\end{array}$ \\
\hline \multirow[t]{3}{*}{ Canada } & $N L I \neq>R Y$ & -1.2214 & 0.2232 & \\
\hline & $\mathrm{NLI}^{+} \neq>R Y^{+}$ & $-1.6749 *$ & 0.0955 & -0.0156 \\
\hline & $N L I^{-} \neq>R Y^{-}$ & $14.9538 * *$ & 0.0000 & 0.7893 \\
\hline \multirow[t]{3}{*}{ France } & $N L I \neq>R Y$ & -1.2632 & 0.2079 & \\
\hline & $N L^{+} \neq>R Y^{+}$ & 0.3019 & 0.7630 & \\
\hline & $N L I^{-} \neq>R Y^{-}$ & $25.2782 * *$ & 0.0000 & 0.9487 \\
\hline \multirow[t]{3}{*}{ Germany } & $N L I \neq>R Y$ & -1.4199 & 0.1571 & \\
\hline & $\mathrm{NLI}^{+} \neq>R Y^{+}$ & 0.1242 & 0.9012 & \\
\hline & $N L I^{-} \neq>R Y^{-}$ & $24.4870 * *$ & 0.0000 & 0.9381 \\
\hline \multirow[t]{3}{*}{ Italy } & $N L I \neq>R Y$ & $-3.9538 * *$ & 0.0001 & -0.0283 \\
\hline & $\mathrm{NLI}^{+} \neq>\boldsymbol{R} Y^{+}$ & -0.5046 & 0.6144 & \\
\hline & $\mathrm{NLI}^{-} \neq>\mathrm{RY}^{-}$ & $17.3562 * *$ & 0.0000 & 0.9154 \\
\hline \multirow[t]{3}{*}{ Japan } & $N L I \neq>R Y$ & $2.3688 * *$ & 0.0187 & 0.0267 \\
\hline & $\mathrm{NLI}^{+} \neq>R Y^{+}$ & $3.6027 * *$ & 0.0004 & 0.0533 \\
\hline & $N L I^{-} \neq>R Y^{-}$ & $22.4371 * *$ & 0.0000 & 1.0056 \\
\hline \multirow[t]{3}{*}{$\mathbf{U K}$} & $N L I \neq>R Y$ & 0.7233 & 0.4703 & \\
\hline & $\mathrm{NLI}^{+} \neq>\mathrm{RY}^{+}$ & 0.3702 & 0.7116 & \\
\hline & $N L I^{-} \neq>R Y^{-}$ & $21.7143 * *$ & 0.0000 & 0.9420 \\
\hline \multirow[t]{3}{*}{ U.S. } & $N L I \neq>R Y$ & $2.0414 * *$ & 0.0424 & 0.0377 \\
\hline & $\mathrm{NLI}^{+} \neq>R Y^{+}$ & 0.8222 & 0.4119 & \\
\hline & $\mathrm{NLI}^{-} \neq>\mathrm{R} Y^{-}$ & $7.6420 * *$ & 0.0000 & 0.8985 \\
\hline
\end{tabular}

Notes: $N L I$ represents non-life insurance per capita and $R Y$ represents gross domestic product per capita. The vector $\left(N L I^{+}, R Y^{+}\right)$signifies the cumulative positive shocks and $\left(\mathrm{NLI}^{-}, R \mathrm{Y}^{-}\right)$denotes the cumulative negative shocks. *,** indicate significance at the $10 \%$ and $5 \%$ level, respectively. 
Table 5 The symmetric and asymmetric panel causality test results for the null hypothesis that GDP per capita does not cause non-life insurance per capita

\begin{tabular}{|c|c|c|c|c|}
\hline Country & Null Hypothesis & Test Values & P-values & $\begin{array}{c}\text { Causal } \\
\text { Parameters }\end{array}$ \\
\hline \multirow[t]{3}{*}{ Canada } & $R Y \neq>N L I$ & $3.9722 * *$ & 0.0001 & 0.8751 \\
\hline & $R Y^{+} \neq>N_{L I}^{+}$ & $3.5442 * *$ & 0.0005 & 0.9399 \\
\hline & $R Y^{-} \neq>N L I^{-}$ & $4.0049 * *$ & 0.0001 & 0.4719 \\
\hline \multirow[t]{3}{*}{ France } & $R Y \neq>N L I$ & 1.5550 & 0.1214 & \\
\hline & $R Y^{+} \neq>N L I^{+}$ & 0.4009 & 0.6889 & \\
\hline & $R Y^{-} \neq>N L I^{-}$ & 1.5787 & 0.1159 & \\
\hline \multirow[t]{3}{*}{ Germany } & $R Y \neq>N L I$ & $2.8289 * *$ & 0.0051 & 0.9378 \\
\hline & $R Y^{+} \neq>N L I^{+}$ & $1.8959 *$ & 0.0593 & 0.5572 \\
\hline & $R Y^{-} \neq>N L I^{-}$ & $1.9293 *$ & 0.0551 & 0.6024 \\
\hline \multirow[t]{3}{*}{ Italy } & $R Y \neq>N L I$ & 0.7032 & 0.4827 & \\
\hline & $R Y^{+} \neq>N_{L I}^{+}$ & 1.1822 & 0.2385 & \\
\hline & $R Y^{-} \neq>N L I^{-}$ & $2.7776 * *$ & 0.0060 & 0.4991 \\
\hline \multirow[t]{3}{*}{ Japan } & $R Y \neq>N L I$ & 0.4622 & 0.6444 & \\
\hline & $R Y^{+} \neq>N L I^{+}$ & $2.4021 * *$ & 0.0172 & 0.9749 \\
\hline & $R Y^{-} \neq>N L I^{-}$ & 0.5059 & 0.6135 & \\
\hline \multirow[t]{3}{*}{ UK } & $R Y \neq>N L I$ & 1.1807 & 0.2390 & \\
\hline & $R Y^{+} \neq>N L I^{+}$ & $3.5876 * *$ & 0.0004 & 1.4900 \\
\hline & $R Y^{-} \neq>N L I^{-}$ & $-2.2414 * *$ & 0.0261 & 0.0000 \\
\hline \multirow[t]{3}{*}{ U.S. } & $R Y \neq>N L I$ & $1.7094 *$ & 0.0888 & 0.4480 \\
\hline & $R Y^{+} \neq>N L I^{+}$ & $3.4354 * *$ & 0.0007 & 0.8158 \\
\hline & $R Y^{-} \neq>N L I^{-}$ & 0.5529 & 0.5809 & \\
\hline
\end{tabular}

Notes: $N L I$ represents non-life insurance per capita and $R Y$ represents gross domestic product per capita. The vector $\left(N \mathrm{II}^{+}, R \mathrm{Y}^{+}\right)$signifies the cumulative positive shocks and $\left(\mathrm{NLI}^{-}, R \mathrm{Y}^{-}\right)$denotes the cumulative negative shocks. $*, * *$ indicate significance at the $10 \%$ and $5 \%$ level, respectively.

As far as the nexus between total life insurance activity and economic performance is concerned, Table 6 presents the causality test results for the impact of total insurance per capita on GDP per capita. The symmetric causal impact runs from total insurance to GDP in the cases of Canada, Italy, Japan, and the U.S. A positive shock in total insurance causes a positive shock in GDP in Canada, Italy, Japan and the U.S. The estimated causal parameter also reveals that development in the non-life insurance market has an uncertain impact on economic performance. Total insurance activity has an adverse influence on economic performance in Canada and Italy, which is in line with the view of 'too much finance'. On the other hand, a negative shock in total insurance causes a negative shock in the GDP of all countries except for the U.S. This suggests that total insurance plays a 
passive role on economic performance. Table 7 shows the results for the income effect on total insurance per capita. There is a symmetric causal impact in Canada, France, Germany and the U.S. A positive shock in GDP causes a positive shock in total insurance in all countries except for France. A negative shock in GDP causes a negative shock in total insurance in Canada, France, and Italy only. This suggests that economic performance plays an aggressive role on insurance activity.

Table 6 The symmetric and asymmetric panel causality test results for the null hypothesis that total insurance per capita does not cause GDP per capita

\begin{tabular}{|c|c|c|c|c|}
\hline Country & Null Hypothesis & Test Values & P-values & $\begin{array}{c}\text { Causal } \\
\text { Parameters }\end{array}$ \\
\hline \multirow[t]{3}{*}{ Canada } & $T I \neq>R Y$ & $-1.6837^{*}$ & 0.0937 & -0.0155 \\
\hline & $\mathrm{TI}^{+} \neq>R Y^{+}$ & $-1.8812 *$ & 0.0613 & -0.0182 \\
\hline & $T I^{-} \neq>R Y^{-}$ & $2.4936 * *$ & 0.0134 & 0.0707 \\
\hline \multirow[t]{3}{*}{ France } & $T I \neq>R Y$ & 0.0538 & 0.9572 & \\
\hline & $T I^{+} \neq>R Y^{+}$ & 1.2647 & 0.2074 & \\
\hline & $T I^{-} \neq>R Y^{-}$ & $2.0111 * *$ & 0.0456 & 0.0071 \\
\hline \multirow[t]{3}{*}{ Germany } & $T I \neq>R Y$ & -0.7997 & 0.4248 & \\
\hline & $T I^{+} \neq>R Y^{+}$ & 0.5023 & 0.6160 & \\
\hline & $T I^{-} \neq>R Y^{-}$ & $2.1146 * *$ & 0.0357 & 0.0146 \\
\hline \multirow[t]{3}{*}{ Italy } & $T I \neq>R Y$ & $-5.3708 * *$ & 0.0000 & -0.0207 \\
\hline & $T I^{+} \neq>R Y^{+}$ & $-2.3711 * *$ & 0.0186 & -0.0151 \\
\hline & $T I^{-} \neq>R Y^{-}$ & $2.3452 * *$ & 0.0200 & 0.0307 \\
\hline \multirow[t]{3}{*}{ Japan } & $T I \neq>R Y$ & $2.5382 * *$ & 0.0118 & 0.0247 \\
\hline & $T I^{+} \neq>R Y^{+}$ & $3.3764 * *$ & 0.0009 & 0.0438 \\
\hline & $T I^{-} \neq>R Y^{-}$ & $3.6965 * *$ & 0.0003 & 0.0193 \\
\hline \multirow[t]{3}{*}{ UK } & $T I \neq>R Y$ & 0.9323 & 0.3522 & \\
\hline & $T I^{+} \neq>R Y^{+}$ & -1.2250 & 0.2219 & \\
\hline & $T I^{-} \neq>R Y^{-}$ & $27.1338^{* *}$ & 0.0000 & 0.0921 \\
\hline \multirow[t]{3}{*}{ U.S. } & $T I \neq>R Y$ & $1.7775 *$ & 0.0769 & 0.0318 \\
\hline & $T I^{+} \neq>R Y^{+}$ & 0.1920 & 0.8479 & \\
\hline & $T I^{-} \neq>R Y^{-}$ & 0.3982 & 0.6909 & \\
\hline
\end{tabular}

Notes: $T I$ represents total insurance per capita and $R Y$ represents gross domestic product per capita. The vector $\left(T I^{+}, R Y^{+}\right)$signifies the cumulative positive shocks and $\left(T I^{-}, R Y^{-}\right)$denotes the cumulative negative shocks. ${ }^{*}, * *$ indicate significance at the $10 \%$ and $5 \%$ level, respectively. 
Table 7 The symmetric and asymmetric panel causality test results for the null hypothesis that GDP per capita does not cause total insurance per capita

\begin{tabular}{|c|c|c|c|c|}
\hline Country & Null Hypothesis & Test Values & P-values & $\begin{array}{c}\text { Causal } \\
\text { Parameters }\end{array}$ \\
\hline \multirow[t]{3}{*}{ Canada } & $R Y \neq>T I$ & $5.9531 * *$ & 0.0000 & 1.0027 \\
\hline & $R Y^{+} \neq>\mathrm{TI}^{+}$ & $4.2592 * *$ & 0.0000 & 0.7652 \\
\hline & $R Y^{-} \neq>T I^{-}$ & $4.4225 * *$ & 0.0000 & 0.5203 \\
\hline \multirow[t]{3}{*}{ France } & $R Y \neq>T I$ & $2.5044 * *$ & 0.0130 & 0.7154 \\
\hline & $R Y^{+} \neq>T^{+}$ & 0.6706 & 0.5032 & \\
\hline & $R Y^{-} \neq>T^{-}$ & $2.7761 * *$ & 0.0060 & 1.2015 \\
\hline \multirow[t]{3}{*}{ Germany } & $R Y \neq>T I$ & $3.7469 * *$ & 0.0002 & 0.9405 \\
\hline & $R Y^{+} \neq>\mathrm{TI}^{+}$ & $3.0359 * *$ & 0.0027 & 0.6420 \\
\hline & $R Y^{-} \neq>T^{-}$ & 1.1407 & 0.2553 & \\
\hline \multirow[t]{3}{*}{ Italy } & $R Y \neq>T I$ & 0.9170 & 0.3602 & \\
\hline & $R Y^{+} \neq>\mathrm{TI}^{+}$ & $3.1900 * *$ & 0.0016 & 1.5769 \\
\hline & $R Y^{-} \neq>T_{I^{-}}$ & $2.6331 * *$ & 0.0091 & 0.6049 \\
\hline \multirow[t]{3}{*}{ Japan } & $R Y \neq>T I$ & 0.8872 & 0.3760 & \\
\hline & $R Y^{+} \neq>T^{+}$ & $2.6648 * *$ & 0.0083 & 1.0685 \\
\hline & $R Y^{-} \neq>T I^{-}$ & 0.5764 & 0.5650 & \\
\hline \multirow[t]{3}{*}{$\mathbf{U K}$} & $R Y \neq>T I$ & 0.4103 & 0.6820 & \\
\hline & $R Y^{+} \neq>T^{+}$ & $2.7336 * *$ & 0.0068 & 0.9334 \\
\hline & $R Y^{-} \neq>T I^{-}$ & 0.1103 & 0.9123 & \\
\hline \multirow[t]{3}{*}{ U.S. } & $R Y \neq>T I$ & $3.0726 * *$ & 0.0024 & 0.5378 \\
\hline & $R Y^{+} \neq>\mathrm{TI}^{+}$ & $5.7401 * *$ & 0.0000 & 0.8478 \\
\hline & $R Y^{-} \neq>T I^{-}$ & 1.4845 & 0.1392 & \\
\hline
\end{tabular}

Notes: $T I$ represents total insurance per capita and $R Y$ represents gross domestic product per capita. The vector $\left(\mathrm{TI}^{+}, R \mathrm{Y}^{+}\right)$signifies the cumulative positive shocks and $\left(\mathrm{TI}^{-}, R \mathrm{Y}^{-}\right)$denotes the cumulative negative shocks. ${ }^{*}, *$ indicate significance at the $10 \%$ and $5 \%$ level, respectively.

\section{FURTHER DISCUSSIONS AND IMPLICATIONS}

Table 8 summarizes the main empirical results in this paper. On the basis of our findings, there are several implication for the asymmetric causal relationship between insurance activities and economic performance. Previous works only draw conclusions regarding the direction of causality, without any overall consensus on the heterogeneity shocks of the causality or the magnitude of the causality. Put differently, our analysis gives a clear picture of whether and how the causal relationship changes with regard to different unexpected shocks. This information would prevent policy-makers and authorities from implementing a 'one size fits all' economic or financial policy. For 
Table 8 Summary of the empirical results on the asymmetric causal relationship between insurance per capita and GDP per capita

\begin{tabular}{|c|c|c|c|c|c|c|}
\hline \multirow{2}{*}{$\begin{array}{l}\text { Country } \\
\text { Canada }\end{array}$} & \multicolumn{2}{|c|}{ Life insurance } & \multicolumn{2}{|c|}{ Non-life insurance } & \multicolumn{2}{|c|}{ Total insurance } \\
\hline & $L I^{-} \neq>R Y^{-}(+)$ & $\begin{array}{l}R Y^{+} \neq>L I^{+}(+) \\
R Y^{-} \neq>L I^{-}(+)\end{array}$ & $\begin{array}{l}N L I^{+} \neq>R Y^{+}(-) \\
N L I^{-} \neq>R Y^{-}(+)\end{array}$ & $\begin{array}{l}R Y^{+} \neq>\boldsymbol{N L I}^{+}(+) \\
\boldsymbol{R} \boldsymbol{Y}^{-} \neq>\boldsymbol{N} \boldsymbol{L I} \mathbf{I}^{-}(+)\end{array}$ & $\begin{array}{l}T I^{+} \neq>R Y^{+}(-) \\
T I^{-} \neq>R Y^{-}(+)\end{array}$ & $\begin{array}{l}R Y^{+} \neq>T I^{+}(+) \\
R Y^{-} \neq>T I^{-}(+)\end{array}$ \\
\hline France & $\begin{array}{l}\boldsymbol{L} \boldsymbol{I}^{+} \neq>\boldsymbol{R} \boldsymbol{Y}^{+}(+) \\
\boldsymbol{L} \boldsymbol{I}^{-} \neq>\boldsymbol{R} \boldsymbol{Y}^{-}(+)\end{array}$ & $R Y^{-} \neq>L I^{-}(+)$ & $N L I^{-} \neq>R Y^{-}(+)$ & & $T I^{-} \neq>R Y^{-}(+)$ & $R Y^{-} \neq>T I^{-}(+)$ \\
\hline Germany & $L I^{-} \neq>R Y^{-}(+)$ & $R Y^{+} \neq>L I^{+}(+)$ & $N L I^{-} \neq>R Y^{-}(+)$ & $\begin{array}{l}\boldsymbol{R} \boldsymbol{Y}^{+} \neq>\boldsymbol{N L I}^{+}(+) \\
\boldsymbol{R} \boldsymbol{Y}^{-} \neq>\boldsymbol{N} \boldsymbol{L I} \mathbf{I}^{-}(+)\end{array}$ & $T I^{-} \neq>R Y^{-}(+)$ & $R Y^{+} \neq>T I^{+}(+)$ \\
\hline Italy & $\begin{array}{l}\boldsymbol{L} \boldsymbol{I}^{+} \neq>\boldsymbol{R} \boldsymbol{Y}^{+}(-) \\
\boldsymbol{L} \boldsymbol{I}^{-} \neq>\boldsymbol{R} \boldsymbol{Y}^{-}(+)\end{array}$ & & $N L I^{-} \neq>R Y^{-}(+)$ & $R Y^{-} \neq>N L I^{-}(+)$ & $\begin{array}{l}T I^{+} \neq>R Y^{+}(-) \\
T I^{-} \neq>R Y^{-}(+)\end{array}$ & $\begin{array}{l}R Y^{+} \neq>T I^{+}(+) \\
R Y^{-} \neq>T I^{-}(+)\end{array}$ \\
\hline Japan & $\begin{array}{l}\boldsymbol{L} \boldsymbol{I}^{+} \neq>\boldsymbol{R} \boldsymbol{Y}^{+}(+) \\
\boldsymbol{L} \boldsymbol{I}^{-} \neq>\boldsymbol{R} \boldsymbol{Y}^{-}(+)\end{array}$ & $R Y^{+} \neq>L I^{+}(+)$ & $\begin{array}{l}N L I^{+} \neq>R Y^{+}(+) \\
N L I^{-} \neq>R Y^{-}(+)\end{array}$ & $R Y^{+} \neq>N L I^{+}(+)$ & $\begin{array}{l}T I^{+} \neq>R Y^{+}(+) \\
T I^{-} \neq>R Y^{-}(+)\end{array}$ & $R Y^{+} \neq>T I^{+}(+)$ \\
\hline UK & $\begin{array}{l}\boldsymbol{L} \boldsymbol{I}^{+} \neq>\boldsymbol{R} \boldsymbol{Y}^{+}(-) \\
\boldsymbol{L} \boldsymbol{I}^{-} \neq>\boldsymbol{R} \boldsymbol{Y}^{-}(+)\end{array}$ & $R Y^{+} \neq>L I^{+}(+)$ & $N L I^{-} \neq>R Y^{-}(+)$ & $\begin{array}{l}\boldsymbol{R} \boldsymbol{Y}^{+} \neq>\boldsymbol{N L I}^{+}(+) \\
\boldsymbol{R} \boldsymbol{Y}^{-} \neq>\boldsymbol{N} \boldsymbol{L I} \mathbf{I}^{-}(+)\end{array}$ & $T I^{-} \neq>R Y^{-}(+)$ & $R Y^{+} \neq>T I^{+}(+)$ \\
\hline U.S. & & $\begin{array}{l}R Y^{+} \neq>L I^{+}(+) \\
R Y^{-} \neq>L I^{-}(+)\end{array}$ & $N L I^{-} \neq>R Y^{-}(+)$ & $R Y^{+} \neq>N L I^{+}(+)$ & & $R Y^{+} \neq>T I^{+}(+)$ \\
\hline
\end{tabular}


example, in the case of Japan, most previous evidence suggests the supply-leading theory, indicating a unidirectional causality running from insurance activities to economic performance (e.g., Chang et al., 2014; Lee et al., 2016). Our results show that this causal relationship only exists for unexpected negative shocks, which means a decrease in insurance market activity will cause a negative influence on economic performance. In this regard, adequate attention should be paid to the decline of insurance activity rather than the rise of insurance activity. In addition, for those unexpected positive shocks, a bidirectional causal relationship between insurance activities and the economy is supported. Insurance market activity and economic performance mutually influence each other, and their reinforcements may have important implications for the conduct of economic or financial policies.

It should also be noted that previous research finds little evidence of insurance's growth effect in Canada and Italy (e.g., Chang et al., 2014; Lee et al., 2016). By separating the positive shocks from the negative ones, we further indicate that insurance market activity can deter economic performance, possibly because they reduce the insured's incentives to engage in prudent behavior and loss mitigation, which is known as moral hazard (Gueyie and Lai, 2003; Haiss and Sümegi, 2008). Governments in these countries should focus more on improving the function provided by the insurance sector and decreasing the risk exposures instead of increasing the scale of insurance activities. Moreover, as to unexpected negative shocks, there are bidirectional causal relationships in Canada for all insurance sectors and in Italy for non-life and total insurance sectors. Given that insurance market activity and economic performance mutually influence each other, this result highlights the need for authorities in these two countries to question the optimal size of insurance and economic systems.

\section{CONCLUSIONS}

While the relationship between insurance market activity and economic performance has been a well-studied topic in recent years, there is only limited knowledge about the exact causal relationships between these two variables. Focusing on this causal relationship in the G7 countries over the period 1980-2014, the present paper employs the advanced asymmetric panel causality tests to investigate the feasibility of the 'supply- 
leading' and 'demand-following' theories in the real world. The main advantage of this asymmetric causality test is that it totally separates the causal impact of positive changes from the negative ones. Our paper thus paints a more complete picture on this topic.

Our main findings are as follows. First, the symmetric panel causality test results show that the causal links between insurance and economic performances are countryspecific, bidirectional, unidirectional, or no relationships in these G7 countries. However, the results of the asymmetric panel causality test indicate that there is a bidirectional causal relationship between these two variables in almost all cases, regardless of whether insurance market activity is proxied by life, non-life, or total insurance. This result suggests that the insurance market and economic performance are both endogenous. On the one hand, insurance market activity contributes to economic growth by allowing different risks to be managed more efficiently and by mobilizing domestic savings. Conversely, as economic performance increases, there is a need for various new financial services, thus leading to the creation of modern financial institutions and the related financial services. Our results encompass the existing findings and offer an explanation to the conflicting findings in previous studies.

Second, when taking into account the asymmetric behavior in causality testing by constructing the cumulative sums of positive and negative shocks, we find that the impacts from positive shocks are different compared to those from negative ones. For positive shocks, the influence of the insurance market is uncertain, which supports the novel view of the too much finance hypothesis and the vanishing effect. This suggests that policy-makers should focus less on increasing the size of the insurance sector and more on improving the sector's function. As to the negative shocks, evidence shows that a reduction in insurance causes a negative influence upon economic performance for almost all countries in the sample. This result suggests that insurance plays a passive role on economic performance. In addition, the causal impact of economic performance on insurance activity reveals that a positive shock results in a positive effect and vice versa, which suggests that a high level of economic performance leads to a high level of real insurance premiums.

Finally, the empirical results also indicate that the impact of insurance market activity on economic performance is variable, asymmetrical, and non-linear. As to the 
intensity of positive shocks and negative shocks, the negative ones have a greater impact than the positive ones. This suggests that a 'one size fits all' policy is unsuitable for modeling the growth process. Policy-makers should be more concerned when insurance activity declines. In addition, there are likely to be different effects on economic performance from life and non-life insurance markets. When comparing the results of life and non-life insurance markets, evidence shows that non-life insurance activity yields greater growth effects compared to life insurance activity. Given that life and non-life insurance protect households and firms from different kinds of risks, it is reasonable that the economic risk faced by the non-life insurance sector is more sensitive than that of mortality risk and longevity risk faced by the life insurance sector. An alternative explanation may be attributed to the increasing role of non-life insurance.

\section{ACKNOWLEDGEMENTS}

The authors are grateful to the Editor and two anonymous referees for helpful comments and suggestions.

\section{ENDNOTES}

${ }^{1}$ As noted by Azman-Saini and Smith (2011), despite the critical role that the insurance sector plays in an economic system, it is often ignored in the finance-growth literature, whereas other components of the financial sector, i.e., banking sector and stock market, attract abundant attention.

2 The Im et al. (2003) tests of panel unit root show non-stationarity in levels for all the four variables, but stationarity in their first difference. Therefore, the positive and negative components can be derived based on the cumulative sums of the growth rates of the variables. In addition, tests for the cross-sectional dependence and homogeneity were also conducted. The tests show that the null hypotheses of no crosssectional dependence and homogeneity are rejected at a $1 \%$ significance level for all the tests. All these results validate the use of our approach. Complete details of these results have been presented in Tables B1 and B2 in the Appendix. 


\section{APPENDIX A: DATA DESCRIPTION}

\section{Table A1}

Descriptive statistics

\begin{tabular}{|c|c|c|c|c|}
\hline Country & Mean & Std. Dev. & Minimum & Maximum \\
\hline \multicolumn{5}{|c|}{ GDP per capita } \\
\hline Canada & $40,321.12$ & $6,322.22$ & $30,916.82$ & $50,275.35$ \\
\hline France & $34,718.08$ & $4,637.83$ & $27,096.70$ & $40,837.43$ \\
\hline Germany & $34,179.76$ & $5,590.41$ & $25,170.38$ & $43,347.08$ \\
\hline Italy & $31,009.80$ & $3,927.09$ & $23,639.42$ & $36,304.51$ \\
\hline Japan & $37,522.77$ & $5,992.63$ & $24,762.26$ & $44,382.93$ \\
\hline UK & $29,801.11$ & $6,703.60$ & $19,330.33$ & $39,178.04$ \\
\hline U.S. & $40,802.44$ & $7,377.29$ & $28,362.39$ & $51,056.05$ \\
\hline \multicolumn{5}{|c|}{ Life insurance per capita } \\
\hline Canada & 771.92 & 433.49 & 226.65 & $1,524.44$ \\
\hline France & $1,359.41$ & 980.90 & 106.70 & $2,969.72$ \\
\hline Germany & 731.42 & 437.82 & 154.70 & $1,436.82$ \\
\hline Italy & 729.80 & 737.30 & 15.92 & $2,331.65$ \\
\hline Japan & $2,545.96$ & $1,070.70$ & 473.25 & $4,095.95$ \\
\hline UK & $2,242.35$ & $1,641.35$ & 284.88 & $6,903.29$ \\
\hline U.S. & $1,167.18$ & 540.58 & 287.84 & $1,922.83$ \\
\hline \multicolumn{5}{|c|}{ Non-life insurance per capita } \\
\hline Canada & 993.62 & 602.67 & 295.23 & $2,136.19$ \\
\hline France & 770.57 & 364.22 & 269.84 & $1,356.03$ \\
\hline Germany & 930.48 & 446.57 & 274.53 & $1,617.49$ \\
\hline Italy & 471.17 & 271.28 & 91.82 & 941.30 \\
\hline Japan & 690.23 & 258.91 & 168.00 & $1,031.39$ \\
\hline UK & 756.27 & 379.08 & 177.50 & $1,375.09$ \\
\hline U.S. & $1,503.73$ & 565.16 & 569.18 & $2,359.93$ \\
\hline \multicolumn{5}{|c|}{ Total insurance per capita } \\
\hline Canada & $1,765.54$ & $1,033.42$ & 521.88 & $3,649.39$ \\
\hline France & $2,129.98$ & $1,336.68$ & 383.16 & $4,264.73$ \\
\hline Germany & $1,661.89$ & 881.72 & 429.23 & $3,054.31$ \\
\hline Italy & $1,200.97$ & 993.28 & 108.32 & $3,078.07$ \\
\hline Japan & $3,236.19$ & $1,327.35$ & 642.86 & $5,105.81$ \\
\hline UK & $2,998.62$ & $1,999.53$ & 480.43 & $8,278.38$ \\
\hline U.S. & $2,670.91$ & $1,097.36$ & 857.02 & $4,109.44$ \\
\hline
\end{tabular}




\section{APPENDIX B: UNIT ROOT, CRPSS-SECTIONAL DEPENDENCE, HOMOGENEITY TESTS}

\section{Table B1}

IPS unit root test results for GDP and non-life, life, and total insurances for G7 countries

\begin{tabular}{|c|c|c|c|c|c|c|c|c|}
\hline \multirow[b]{2}{*}{ IPS unit root } & \multicolumn{2}{|c|}{ GDP } & \multicolumn{2}{|c|}{ Life Insurance } & \multicolumn{2}{|c|}{ Non-Life Insurance } & \multicolumn{2}{|c|}{ Total Insurance } \\
\hline & Constant & $\begin{array}{l}\text { Constant } \\
\text { and trend }\end{array}$ & Constant & $\begin{array}{l}\text { Constant } \\
\text { and trend }\end{array}$ & Constant & $\begin{array}{l}\text { Constant } \\
\text { and trend }\end{array}$ & Constant & $\begin{array}{l}\text { Constant } \\
\text { and trend }\end{array}$ \\
\hline Level & -0.7708 & 2.0117 & -1.2603 & 1.5658 & -0.9323 & -0.1806 & -0.9943 & 0.8641 \\
\hline First-difference & $-6.2519 * * *$ & $-6.9708 * * *$ & $-5.2907 * * *$ & $-5.5057 * * *$ & $-4.7354 * * *$ & $-4.0964 * * *$ & $-4.9953 * * *$ & $-4.7923 * * *$ \\
\hline
\end{tabular}

Notes: Entries denote the W-stats. ${ }^{* * *}$ indicates the rejection of the null hypothesis of unit root at the $1 \%$ level.

\section{Table B2}

Cross-sectional dependence and homogeneity tests for G7 countries

\begin{tabular}{llll}
\hline Tests & Life Insurance & Non-Life Insurance & Total Insurance \\
\hline$C D_{B P}$ & $225.6490^{* * * *}$ & $229.8650^{* * * *}$ & $231.7370^{* * *}$ \\
$C D_{L M}$ & $31.5780^{* * *}$ & $32.2290^{* * *}$ & $32.5170^{* * * *}$ \\
$C D$ & $14.3430^{* * *}$ & $14.4550^{* * *}$ & $14.5060^{* * *}$ \\
$\tilde{\Delta}$ & $16.8329^{* * *}$ & $13.3901^{* * *}$ & $14.7523^{* * *}$ \\
$\tilde{\Delta}_{\text {adj }}$ & $17.5814^{* * *}$ & $13.9855^{* * *}$ & $15.4083^{* * *}$ \\
Swamy Shat & $69.9828^{* * *}$ & $84.3208^{* * *}$ & $41.2472^{* * *}$ \\
\hline
\end{tabular}

Notes: *** indicates significance at the $1 \%$ level. The tests are the Bresusch and Pagan (1980) test $\left(\mathrm{CD}_{\mathrm{BP}}\right)$, the Lagrange Multiplier test $\left(\mathrm{CD}_{\mathrm{LM}}\right)$, and Pesaran's (2004) test (CD)) and homogeneity (the $\tilde{\Delta}$ and $\tilde{\Delta}_{\text {adj }}$ tests by Pesaran and Yamagata (2008), and a modified version of the Swamy (1970) test proposed by Pesaran and Yamagata (Swamy Shat, 2008). 


\section{References}

Arcand, J. L., Berkes, E., \& Panizza, U. (2015). Too much finance? Journal of Economic Growth, 20(2), 105-148.

Azman-Saini, W. N. W., \& Smith, P. (2011). Finance and growth: New evidence of the role of insurance. South African Journal of Economics, 79(2), 111-127.

Beck, T., \& Webb, I. (2003). Economic, demographic, and institutional determinants of life insurance consumption across countries. The World Bank Economic Review, $17(1), 51-88$.

Beenstock, M., Dickinson, G., \& Khajuria, S. (1988). The relationship between propertyliability insurance premiums and income: An international analysis. The Journal of Risk and Insurance, 55(2), 259-272.

Browne, M. J., \& Kim, K. (1993). An international analysis of life insurance demand. The Journal of Risk and Insurance, 60(4), 616-634.

Chang, T., Lee, C. C., \& Chang, C. H. (2014). Does insurance activity promote economic growth? Further evidence based on bootstrap panel Granger causality test. The European Journal of Finance, 20(12), 1187-1210.

Dorfman, M. S. (2008). Introduction to Risk Management and Insurance, $9^{\text {th }}$ ed. Pearson Prentice Hall, New Jersey.

Fischer, S. (1973). A life cycle model of life insurance purchases. International Economic Review, 14(1), 132-152.

Gueyie, J. P., \& Lai, V. S. (2003). Bank moral hazard and the introduction of official deposit insurance in Canada. International Review of Economics \& Finance, 12(2), 247-273.

Haiss, P., \& Sümegi, K. (2008). The relationship between insurance and economic growth in Europe: A theoretical and empirical analysis. Empirica, 35(4), 405-431.

Haiss, P., Juvan, H., \& Mahlberg, B. (2016). The impact of financial crises on the finance-growth relationship: A European perspective. Economic Notes, 45(3), 423444.

Hakansson, N. H. (1969). Optimal investment and consumption strategies under risk, an uncertain lifetime, and insurance. International Economic Review, 10(3), 443-466.

Hatemi-J, A. (2011). Asymmetric panel causality tests with an application to the impact of fiscal policy on economic performance in Scandinavia. MPRA Paper No. 55527, University Library of Munich, Germany.

Hatemi-J, A. (2012). Asymmetric causality tests with an application. Empirical Economics, 43(1), 447-456.

Hatemi-J, A., Ajmi, A. N., EI Montasser, G., Inglesi-Lotz, R., \& Gupta, R. (2016). Research output and economic growth in G7 countries: New evidence from asymmetric panel causality testing. Applied Economics, 48(24), 2301-2308.

Im, K. S., Pesaran, M. H., \& Shin, Y. (2003). Testing for unit roots in heterogeneous panels. Journal of Econometrics, 115(1), 53-74.

Inglesi-Lotz, R., Balcilar, M., \& Gupta, R. (2014). Time-varying causality between research output and economic growth in US. Scientometrics, 100(1), 203-216.

Karni, E., \& Zilcha, I. (1985). Uncertain lifetime, risk aversion and life insurance. Scandinavian Actuarial Journal, 1985(2), 109-123.

Kugler, M., \& Ofoghi, R. (2005). Does insurance promote economic growth? Evidence from the UK. Working paper, Division of Economics, University of Southampton. 
Law, S. H., \& Singh, N. (2014). Does too much finance harm economic growth? Journal of Banking \& Finance, 41, 36-44.

Lee, C. C. (2013). Insurance and real output: The key role of banking activities. Macroeconomic Dynamics, 17, 235-260.

Lee, C. C., Change, C. H., Arouri, M., \& Lee, C. C. (2016). Economic growth and insurance development: The role of institutional environments. Economic Modelling, 59, 361-369.

Lee, C. C., Lee, C. C., \& Chiu, Y. B. (2013). The link between life insurance activities and economic growth: Some new evidence. Journal of International Money and Finance, 32, 405-427.

Lewis, F. D. (1989). Dependents and the demand for life insurance. The American Economic Review, 79(3), 452-467.

McMillan, D. G. (2003). Non-linear predictability of UK stock market returns. Oxford Bulletin of Economics and Statistics, 65(5), 557-573.

Njegomir, V., \& Stojić, D. (2010). Does insurance promote economic growth: The evidence from ex-Yugoslavia region. Ekonomska Misao I Praksa, 19(1), 31-48.

Outreville, J. F. (1990). The economic significance of insurance markets in developing countries. The Journal of Risk and Insurance, 57(3), 487-498.

Outreville, J. F. (2013). The relationship between insurance and economic development: 85 empirical papers for a review of the literature. Risk Management and Insurance Review, 16(1), 71-122.

Patrick, H. T. (1966). Financial development and economic growth in underdeveloped countries. Economic Development and Cultural Change, 14(2), 174-189.

Pesaran, M. H. (2004). General diagnostic tests for cross section dependence in panels. CESifo Working Papers No.1233, 255-60.

Pesaran, M. H., \& Yamagata, T. (2008). Testing slope homogeneity in large panels. Journal of Econometrics, 142, 50-93.

Rejda, G. E. (2005). Principles of Risk Management and Insurance (9th ed.). Addison Wesley, Boston.

Rousseau, P. L., \& Wachtel, P. (2011). What is happening to the impact of financial deepening on economic growth? Economic Inquiry, 49(1), 276-288.

Samargandi, N., Fidrmuc, J., \& Ghosh, S. (2015). Is the relationship between financial development and economic growth monotonic? Evidence from a sample of middleincome countries. World Development, 68, 66-81.

Skipper, H. D., \& Kwon, W. J. (2007). Risk Management and Insurance: Perspective in a Global Economy. Blackwell Publishing, Ltd., Oxford.

Stiglitz, J. E. (1974). Incentives and risk sharing in sharecropping. The Review of Economic Studies, 41(2), 219-255.

Swamy, P. A. V. B. (1970). Efficient inference in a random coefficient regression model. Econometrica, 38, 311-323.

Swiss Reinsurance Company (1980-2015). Various Years. (Sigma, Zurich).

Toda, H. Y., \& Yamamoto, T. (1995). Statistical inference in vector autoregressions with possibly integrated processes. Journal of Econometrics, 66(1-2), 225-250.

Ward, D., \& Zurbruegg, R. (2000). Does insurance promote economic growth? Evidence from OECD countries. The Journal of Risk and Insurance, 67(4), 489-506.

WDI (2015). World Development Indicators. World Development Report. The World 
Bank, Washington, DC.

Webb, I. P., Grace, M. F., \& Skipper, H. D. (2005). The effect of banking and insurance on the growth of capital and output. SBS Revista de Temas Financieros, 2(2), 1-32.

Westerlund, J. (2007). Testing for error correction in panel data. Oxford Bulletin of Economics and Statistics, 69(6), 709-748.

Yarri, M. E. (1965). Uncertain lifetime, life insurance, and the theory of the consumer. The Review of Economic Studies, 32(2), 137-150. 